\title{
Investasi Asing Melimpah di Tengah Institusi Yang Buruk di Tiongkok
}

\author{
Puguh Toko Arisanto \\ Program Studi Hubungan Internasional, Universitas Teknologi Yogyakarta - Indonesia \\ Email: ptas002@gmail.com
}

Submitted: 22 April 2020 | Accepted: 30 June 2020

\begin{abstract}
China has become the world's second largest FDI destination in recent years, despite its poor institution status. The success of China seems to undermine the existing theoretical paradigm that good institutions are significantly determinant factors to attract FDI. This paper aims to explain three locational advantages possessed by China which are domestic market, relatively low wages and broad global market access as attracting factors to FDI inflow amid poor institutions. Furthermore, this paper will explain correlation of FDI with poor institutions in China from some elements of governance.
\end{abstract}

Key Words: FDI, Institutions, Locational Advantages, Governance, Tiongkok.

\begin{abstract}
Abstrak
Tiongkok telah menjadi negara destinasi FDI terbesar kedua dunia dalam beberapa tahun belakangan meskipun Tiongkok memiliki institusi yang buruk. Keberhasilan Tiongkok ini seakan meruntuhkan paradigma teoritis bahwa institusi yang baik adalah faktor penting dalam menarik FDI. Tulisan ini bertujuan menjelaskan tiga locational advantages yang dimiliki Tiongkok yakni mangsa pasar domestik yang melimpah, upah buruh yang relatif rendah dan akses pasar global yang luas sebagai faktor yang menarik FDI masuk ke Tiongkok di tengah institusi-institusi yang buruk. Selanjutnya, tulisan ini juga akan memberikan eksplanasi korelasi FDI dengan institusi yang buruk di Tiongkok dari beberapa elemen dalam pemerintahan.
\end{abstract}

Kata Kunci: FDI, Institusi, Locational Advantages, Pemerintahan, Tiongkok.

\section{PENDAHULUAN}

Salah satu konsep yang muncul dalam transisi pembangunan negaranegara dunia pada akhir Perang Dingin adalah Good Governance (GG) atau pemerintahaan yang baik. Konsep GG muncul pertama kali pada tahun pertengahan 1980-an dengan lebih menekankan hanya pada rule of law atau kepastian hukum (Tripathi, 2017). Seiring dengan berakhirnya Perang Dingin dan krisis Asia 1998, konsep tersebut mulai terdengar dalam lingkungan administrasi negara-negara dunia khususnya negara berkembang dalam menyambut era globalisasi. Pada saat yang bersamaan, kebijakan liberalisasi dinilai gagal menciptakan kesejahteraan karena struktur institusi negara-negara berkembang belum berjalan dengan baik. Konsep GG dinilai menjadi solusi dengan cakupan yang lebih luas dan menjadi seperangkat sistem yang (seharusnya) diadopsi negara-negara dunia berdasarkan standar International Development Policy Establishment (IDPE) 
(Oatley, 2012). Konsep GG kemudian menjadi standar baku untuk terciptanya good institutions (institusi yang baik).

Institusi yang baik merujuk kepada sistem demokrasi, birokrasi yang bersih dan efisien (salah satunya minim korupsi) pengadilan yang independen, perlindungan yang kuat terhadap hak kekayaan intelektual, pengelolaan perusahaan-perusahaan yang berorientasi pada pasar dan institusi keuangan yang kuat (Chang, 2002). Dalam konteks ekonomi, institusi yang baik dinilai sebagai sokoguru bagi pembangunan ekonomi. Hal ini berarti pembangunan ekonomi dapat berjalan dengan baik ketika negara memiliki institusi yang baik (Hayat, 2019). Hal yang sama juga berlaku pada sektor Foreign Direct Investment (FDI) atau investasi asing langsung sebagai salah satu modal penting dalam pembangunan ekonomi suatu negara. Berbagai literatur telah menunjukkan bahwa GG yang merujuk pada institusi yang baik yang dimiliki sebuah negara berkorelasi positif terhadap jumlah FDI yang masuk (Shah \& Afridi, 2015). Hal ini berarti institusi yang baik akan meningkatkan FDI dari Multinational Corporations (MNCs) yang masuk ke negara tersebut dan sebaliknya institusi yang buruk berpotensi besar menghambat FDI yang masuk. Dengan adanya institusi yang baik, kepercayaan MNCs terhadap jaminan investasi langsung mereka juga akan meningkat dan pada gilirannya akan semakin banyak menarik FDI ke negara tersebut. Pendekatan ini kemudian diyakini dan diadopsi oleh negara-negara dunia bahwa untuk mewujudkan pembangunan ekonomi khususnya menarik FDI dalam jumlah besar negara-negara perlu memiliki institusi yang baik.

Meskipun institusi yang baik diklaim dapat meningkatkan FDI, tetapi hal ini tidak berlaku bagi Tiongkok. Tiongkok merupakan contoh negara terbaik yang meruntuhkan pendekatan di atas bahwa ternyata poor institutions atau institusi yang buruk juga dapat menarik FDI dalam jumlah yang besar. Tiongkok telah mereformasi kebijakan ekonomi terpusat sebagai ciri khas komunis menjadi ekonomi pasar pada tahun 1978. Meskipun begitu, permasalahan yang berkaitan dengan institusi yang buruk masih menjadi pekerjaan berat bagi Tiongkok. Dalam beberapa tahun terakhir, Tiongkok masih dikenal sebagai negara yang memiliki institusi yang buruk. Ini disebabkan oleh beberapa hal yaitu kondisi perundang-undangan yang sering berubah, birokrasi dan administrasi yang kompleks, kurang transparan, korupsi tinggi dan perlindungan hak kekayaan intelektual yang lemah (Santandertrade, 2019). 
Apalagi Tiongkok bukanlah negara demokrasi pada umumnya. Berdasarkan ranking dari Bank Dunia pada aspek-aspek tersebut, iklim bisnis di Tiongkok menempati urutan ke 78 negara pada tahun 2017 dan urutan ke 46 pada tahun 2018 (World Bank, 2018). Selain itu berdasarkan indeks persepsi korupsi, Tiongkok menempati posisi ke 87 dari dari 180 negara dunia tahun 2018 (Transparency, 2019). Data lain menujukkan kasus-kasus korupsi, skandal, penggelapan, penegakkan hukum dan perlindungan yang lemah terhadap kekayaan intelektual menjadi masalah besar dalam proses mewujudkan institusi yang baik di Tiongkok (Fan, Morck, Xu \& Yeung, 2007). Dibandingkan dengan Amerika Serikat (AS) sebagai negara destinasi FDI terbesar di dunia, berbagai aspek kualitas institusi di Tiongkok masih tertinggal jauh. Ini bisa dilihat dari gambar di bawah ini:

Gambar 1. Komparasi Indeks Kualitas Pemerintahan AS \& Tiongkok 2015

Figure 1: The United States outperforms China on existing quality of government indices

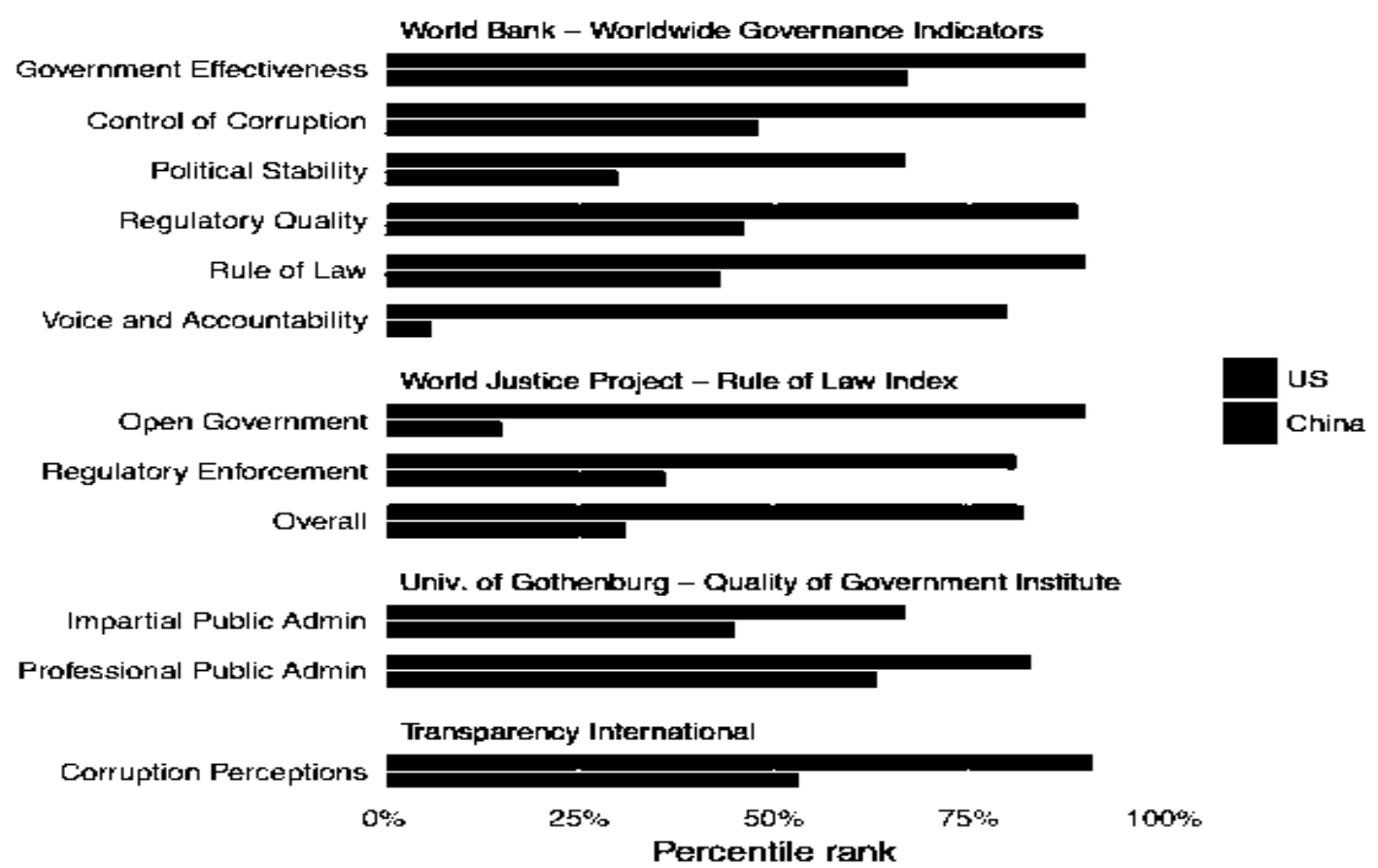

Notes. Percentile ranks $\{100 \%$ indicates top percentile, $50 \%$ indicates median) for the United States and China in selected national governance indicators in 2015 or most recently available prior year.

Sumber: Boittin, Distelhorst \& Fukuyama, 2016.

Meskipun memiliki institusi yang buruk, Tiongkok telah menjadikan FDI yang masuk sebagai modal yang penting bagi pembangunan dan pertumbuhan ekonominya dalam satu dekade terakhir. Tercatat dalam $W$ orld 
Investment Report tahun 2017, total FDI yang masuk ke Tiongkok mencapai US\$136 milliar dolar. Dengan jumlah sebesar itu, Tiongkok menjadi negara destinasi FDI terbesar kedua dunia setelah AS dan satu tingkat di atas Hongkong. Tahun 2017, investor FDI terbesar berasal dari Hongkong (75\%), Singapura (3.7\%), Taiwan (3.6), Korea Selatan, Jepang dan AS di bawah 3\% (Santandertrade, 2019). Terlepas bahwa Hongkong masih diklaim sebagai wilayah dari Tiongkok, tulisan ini hendak menjelaskan masuknya FDI ke negara tersebut meskipun memiliki institusi yang buruk dengan menggunakan pendekatan Locational Advantages. Selanjutnya, tulisan ini juga akan menjelaskan mengenai korelasi FDI dan institusi sebuah negara yang dilihat dari tiga elemen dalam pemerintahan.

\section{KERANGKA TEORITIS}

\section{Konsep Locational Advantages}

FDI telah lama diyakini mampu meningkatkan pembangunan dan pertumbuhan ekonomi negara penerima sehingga banyak negara dunia yang mencoba menarik FDI dengan beberapa instrumen insentif seperti tax boliday, tax allowance, jaminan investasi dan sebagainya. Bahkan karena FDI dianggap begitu penting, dalam beberapa kasus, tidak sedikit negara-negara berkembang yang menerapkan prinsip race to the bottom hanya untuk menarik FDI.

Masuknya FDI ke sebuah negara tidak lepas dari minat investor asing baik oleh perusahaan asing maupun MNCs sebagai penyedianya. Alasan sebuah perusahaan asing (sebelum menjadi

MNCs) menginternasionalisasikan operasinya tidak berbeda dengan alasan MNCs melabuhkan FDI-nya di suatu negara tertentu atau negara host (penerima). Singkatnya, ini berkaitan dengan faktor apa yang menarik atau mendorong sebuah MNC melabuhkan FDI-nya di negara host (penerima). Dari perspektif MNCs, pertimbangan untuk melabuhkan FDI ke negara tujuan adalah locational advantages. Locational advantages merujuk pada karakteristik tertentu suatu negara yang dinilai menguntungkan bagi MNCs untuk melabuhkan FDI-nya. Dengan kata lain, ini berkaitan dengan daya tarik apa yang dimiliki suatu negara sehingga mampu menarik MNCs untuk berinvestasi di negara tersebut. Ada 3 karakteristik yang menarik MNCs untuk berinvestasi melalui FDI-nya di negara penerima yaitu sumber daya alam yang melimpah, mangsa pasar yang besar, dan kesempatan untuk meningkatkan efisiensi operasi MNCs (Oatley, 2012).

Pertama yaitu faktor a large reserve of natural resources atau sumber daya alam yang melimpah. Sumber daya 
alam yang melimpah sebagai faktor given yang dimiliki oleh suatu negara mendorong MNCs untuk berinvestasi pada industri yang bahan bakunya langsung alam atau industri ekstraktif seperti industri pertambangan. Yang kedua adalah a large local market atau mangsa pasar yang besar. Locational advantages kedua ini menarik MNCs untuk berinvestasi pada sektor yang berorientasi pada pasar yang jumlah konsumennya melimpah seperti indusri makanan dan minuman dan industri pada sektor keuangan. Dengan jumlah mangsa pasar yang melimpah, MNCs dapat menjual produknya lebih mudah apalagi jika persaingan produk lokal di negara host relatif kecil. Yang terakhir adalah opportunities to enhance the efficiency of the firm's operations atau kesempatan untuk meningkatkan efisiensi operasi MNCs. MNCs seperti ini biasanya berorientasi pada sektor padat karya seperti industri garmen. Kesempatan efisiensi dalam konteks ini merujuk pada kesempatan untuk memperoleh biaya produksi yang lebih rendah. Ini bisa diperoleh dari upah buruh yang lebih rendah dari unskilled labors dengan jumlah yang sangat besar (Oatley, 2012). Dari tiga karakteristik di atas, MNCs bisa melabuhkan FDInya karena satu karakteristik atau bahkan semua karakteristik di miliki negara host. Ini berarti bahwa semakin besar karakteristik yang dimiliki sebuah negara berpotensi semakin besar kesempatan untuk memperoleh keuntungan yang lebih besar.

Sejalan dengan locational advantages, dalam teori MNCs konvensional yang dikembangkan oleh Hymer, Kindleberger, Heckscher, Ohlin dkk menyebutkan bahwa ada empat motif yang menjadi dasar perilaku investasi sebuah MNC yaitu resource seeking FDI, efficiency seeking FDI, market seeking FDI dan strategic asset/capability seeking FDI (Taube \& Ogutcu, 2002). Resourceseeking FDI merujuk pada upaya MNCs untuk memperoleh sumber-sumber tertentu yang tidak tersedia di negara home (negara asal MNCs) seperti bahan mentah atau sumber daya alam tertentu dan upah buruh yang murah. Efficiency seeking FDI merujuk pada upaya MNCs untuk meningkatkan efisiensinya dengan mengambil keuntungan dari skala ekonomi dan jangkauannya itu turun biaya produksi per unit karena volume yang meningkat dan jenis out put barang yang lebih beragam. Market seeking FDI merujuk pada upaya MNCs untuk mencari potensi pasar negara tujuan dengan mangsa pasar yang melimpah. Selain itu, ini juga dalam rangka lebih mendekatkan kepada konsumen sekaligus mengadaptasikan produk dengan rasa lokal atau kebutuhan lokal sehingga memperkuat basis pasar dari para pesaing. Strategic asset seeking merujuk pada motivasi MNCs untuk memperoleh brands, buman capital, distribution network $\mathrm{dkk}$ 
(Fruman, 2016)

sehingga memungkinkan bersaing dengan perusahaan-perusahan yang sudah ada.

\section{ANALISIS DAN PEMBAHASAN}

\section{Locational Advantages Tiongkok sebagai Daya Tarik FDI}

FDI yang masuk ke Tiongkok dalam jumlah yang besar dalam dua dekade terakhir menjadi hal yang tidak mengejutkan jika dilihat dengan pendekatan locational advantages yang ditawarkan oleh Tiongkok. Locational advantages yang dimiliki Tiongkok yaitu

\section{Jumlah Konsumen Domestik yang Sangat Besar.}

Tiongkok adalah negara yang memiliki penduduk terbesar di dunia yang mencapai 1,7 milliar jiwa. Jumlah ini jauh lebih besar daripada total jumlah penduduk dalam satu kawasan seperti Asia Tenggara. Jumlah yang begitu besar akan menjadi daya tarik yang besar bagi investor khususnya MNCs yang berorientasi pada market seeking karena terdapat jumlah konsumen yang sangat melimpah. Para investor memperkirakan produkproduk mereka akan dibeli oleh konsumen. Orientasi market seeking dari para investor bisa dilihat dari grafik di bawah ini:
Diagram.1 Sektor Destinasi FDI ke Tiongkok 2017

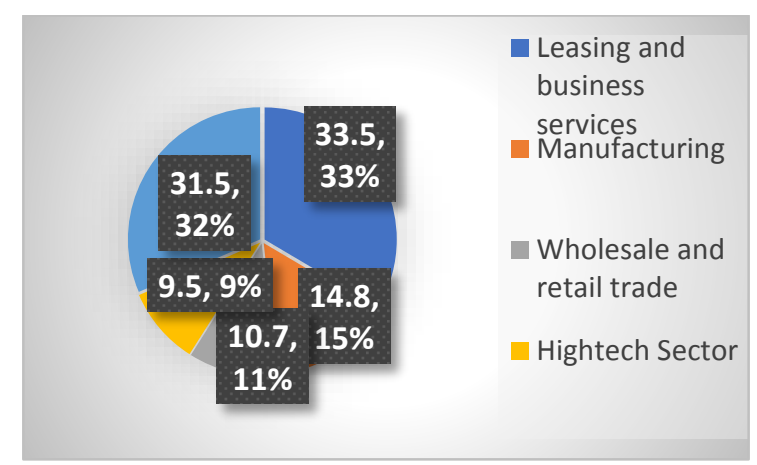

Sumber: santandertrade.com, 2019.

Berdasarkan data di atas, tiga sektor yang mendominasi destinasi FDI ke Tiongkok yakni leasing and business service, manufacturing dan wholesale and retail trade. Dengan semakin terbukanya Tiongkok terhadap pasar global dan jumlah penduduk yang begitu besar, aktivitas bisnis di Tiongkok semakin meningkat. Sektor leasing and business service atau jasa-jasa pembiayaan modal maupun berbagai jasa bisnis lainnya baik kepada individu maupun perusahaan-perusahaan semakin dibutuhkan untuk kepentingan bisnis dalam satu dekade terakhir. Ini bisa dilihat dari indeks aktifitas bisnis jasa di Tiongkok yang meningkat menjadi 54.5 pada bulan April 2019 (Jiefei, 2019). Sektor manufacturing dan wholesale and retail trade juga berpotensi memperoleh keuntungan yang besar. Dengan potensi konsumen yang melimpah, Tiongkok menjadi sasaran investasi di sektor manufaktur. Hasil produksi produk-produk manufaktur yang besar 
dapat dijual ke pasar domestik yang melimpah maupun ke luar negeri dengan harga yang jauh lebih murah. Sektor perdagangan ritel dan grosir juga mendominasi destinasi FDI ke Tiongkok. Sama dengan dua sektor di atas, sektor perdagangan ritel dan grosir juga menarik para investor mengingat mangsa pasar domestik yang sangat besar.

\section{Upah Buruh yang Relatif Rendah}

Upah buruh yang relatif rendah menjadi daya tarik tersendiri bagi MNCs untuk mendaratkan investasinya. Upah buruh menjadi variabel yang penting bagi aktifitas bisnis karena sangat berpengaruh terhadap biaya produksi yang dihasilkan. Semakin rendah upah buruh semakin rendah biaya yang dikeluarkan untuk biaya produksi. Umumnya, para investor yang berorientasi efficiency seeking dan resource seeking sering kali berinvestasi langsung di negara lain karena upah buruh yang relatif rendah sehingga bisa menekan biaya produksi dan pada gilirannya mengakibatkan harga produk yang dihasilkan lebih murah. Sebagai negara yang memiliki jumlah penduduk terbesar yang sekaligus menjadi penyedia sumber daya pekerja terbesar di dunia, Tiongkok tentunya berupaya bagaimana sumber daya pekerja ini bisa hidup dengan penciptaan lapangan pekerjaan yang luas khususnya untuk unskilled labors yang jumlanya jauh lebih besar dari skilled labors.

Salah satu strategi konvensional yang paling disoroti dari Tiongkok adalah penerapan kebijakan standar upah buruh yang murah disamping kebijakan devaluasi mata uang yuan yang diklaim ilegal oleh negara-negara barat. Ini ditujukan tidak lebih agar penduduk minimal bisa bertahan hidup, mengingat pascareformasi ekonomi 1978, 90\% penduduk Tiongkok hidup dalam kemiskinan dengan upah per hari tidak lebih dari US $\$ 2$ dolar (Allison, 2015). Ini juga merupakan salah satu tindakan race to the bottom Tiongkok agar menarik FDI yang masuk untuk menciptakan lapangan pekerjaan yang luas dan mendorong ekspor besar-besaran sehingga pada gilirannya akan menciptakan pertumbuhan ekonomi (a low wages growth strategy).

Upah buruh yang murah awalnya diterapkan sejak tahun 1978 hingga tahun 2000an. Meskipun rata-rata upah buruh mengalami kenaikan setiap tahun, tetapi jika dibandingkan negara industri lainnya seperti negara-negara Eropa, Jepang, Korea, Meksiko dan sebagainya rata-rata upah buruh di Tiongkok tergolong rendah. Bahkan biaya untuk upah buruh di Tiongkok hanya $25 \%$ hingga $40 \%$ dari biaya untuk upah buruh di AS (Ceglowski \& Gollub, 2007). Tercatat tahun 19972007, rata-rata upah buruh di 
Tiongkok mengalami kenaikan tiga kali lipat (Yang, Chen \& Monarch, 2010). Rata-rata upah buruh di kota besar seperti Shanghai, Beijing dan Shenzhen mengalami kenaikan dua kali lipat sejalan dengan pesatnya perekonomian Tiongkok dan melemahnya perekonomian global pada tahun 2010 (China Labour Bulletin, 2019).

Kondisi upah buruh yang rendah setidaknya terjadi hingga mendekati tahun 2010. Seiring dengan perkembangan perekonomian Tiongkok yang luar biasa, tuntutan terhadap kesejahteraan para buruh pun meningkat. Kekawatiran terhadap upah buruh yang semakin tinggi telah diprediksi. Realita kenaikan upah buruh yang signifikan di Tiongkok menjadi hal yang tidak terhindarkan bagi para investor yang ingin berbisnis di Tiongkok. Di sisi lain, Tiongkok diklaim kehilangan salah satu daya tarik bagi destinasi FDI karena faktor buruh (Plekhanov, 2017). Mulai tahun 2016, Tiongkok tidak lagi menjadi negara yang memiliki keunggulan komparatif dalam hal upah buruh yang murah jika dibandingkan dengan negara-negara lainnya. Ini bisa dilihat dari grafik di bawah ini:

Grafik 1. Upah Rata-Rata Buruh di Tiongkok 2009 dan 2016

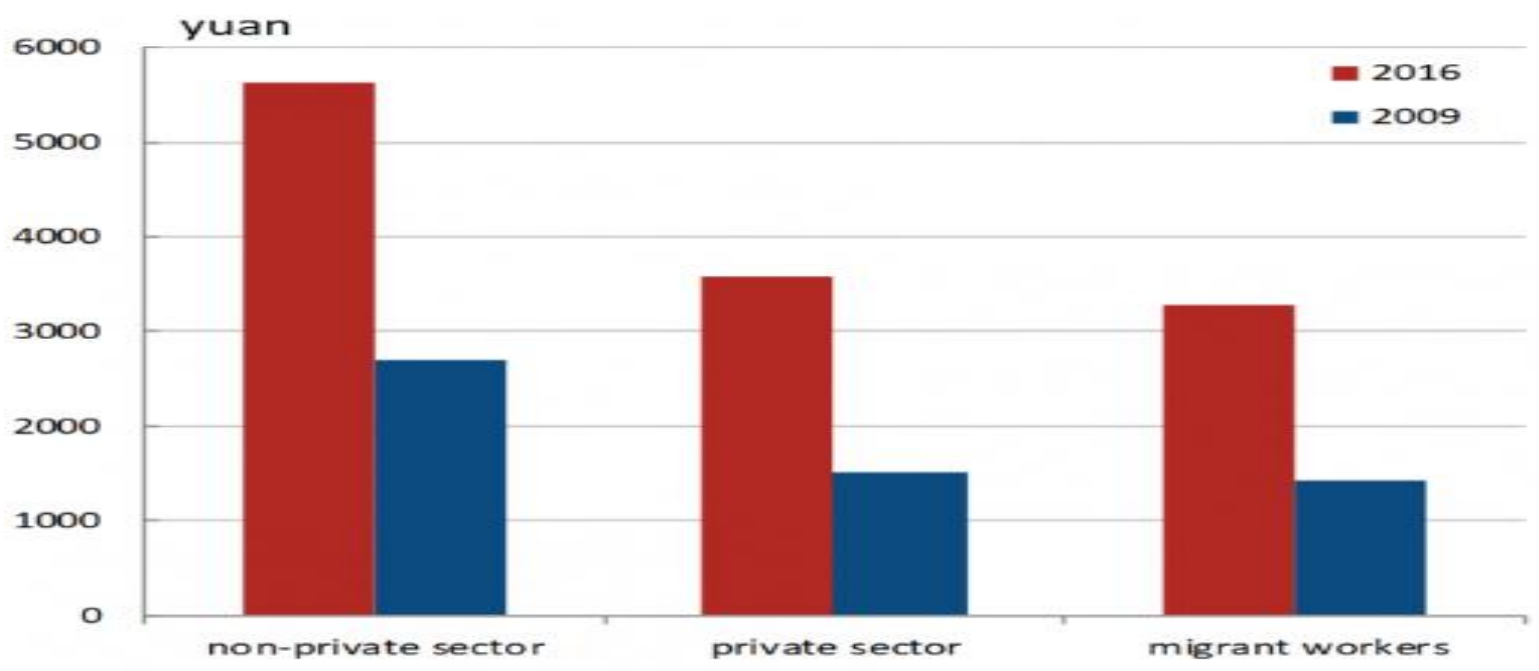

Sumber: NBS dalam Plekhanov, 2017.

Data di atas menunjukkan bahwa dari tahun 2009 hingga 2016, upah buruh di Tiongkok mengalami kenaikan secara signifikan dan diestimasikan naik dua kali lipat dari tahun 2009 hingga 2016. Tahun 2016, Di sektor non swasta rata-rata upah buruh per bulan mencapai 5631 yuan atau sekitar US $\$ 850$ dolar. Di sektor non swasta khususnya di perusahaan milik negara (state owned enterprise) Tiongkok, upah rata-rata per bulan mencapai 6045 Yuan atau sekitar US $\$ 913$ dolar. Meskipun tidak sebesar 
sektor non swasta, rata-rata upah buruh di sektor swasta dan sektor migran masing-masing mencapai 3569 Yuan (US\$539 dolar) dan 3275 Yuan (US\$495 dolar. Jika rata-rata upah buruh terendah (golongan pekerja migran) yakni US\$495 dolar dikonversikan menjadi rupiah dengan estimasi US $\$ 1$ dolar sama dengan Rp 14.000 maka rata-rata upah buruh di Tiongkok minimal sebesar hampir Rp 7 juta. Angka ini tentu lebih besar dibandingkan rata-rata upah buruh di negara lain seperti Indonesia, Vietnam, Thailand, Filipina, Bangladesh dan negara-negara berkembang lainnya.

\section{Akses Pasar Global yang Luas sebagai Akibat dari Favorable Policies}

Secara geografis, wilayah Tiongkok berada di jalur yang strategis yakni dekat dengan pasar-pasar negara Asia, Jepang dan berada di jalur depan lautan Asia. Dengan kata lain Tiongkok berada di antara wilayah Asia Tenggara, Asia Timur (Jepang dan Korea), dekat dengan Asia Barat dan Eropa khususnya Rusia. Selain lokasinya yang strategis, pascareformasi ekonomi 1978, Tiongkok telah menjadi negara yang lebih terbuka. Tiongkok mengadopsi strategi pembangungan yang mengedepankan pada promosi ekspor yang sebesar-besarnya. Strategi ini menjadi langkah yang fundamental dalam menarik lebih banyak FDI sebagai modal untuk memproduksi barang-barang ekspor. Sejalan dengan strategi tersebut, Tiongkok juga mengimplementasikan berbagai macam kebijakan yang sangat liberalis seperti open door policy dan berbagai perjanjian bilateral, regional maupun unilateral dalam perdagangan internasional (Bose, 2012). Dengan berbagai upaya Tiongkok tersebut, Tiongkok pada akhirnya mampu menciptakan akses pasar global yang luas di semua benua di dunia. Selain itu dengan berbagai perjanjian perdagangan dengan negara-negara dunia atau blok perdagangan lain, tarif yang dikenakan untuk produk-produk yang berasal dari Tiongkok juga relatif lebih rendah. Ini tentunya menjadi faktor-faktor yang menggiurkan bagi MNCs atau investor asing mengingat bahwa akses pasar yang tidak terbatas ke pasar global dan semakin hilangnya hambatan-hambatan perdagangan berupa tarif impor yang rendah, kuota dan sebagianya merupakan konsiderasi-konsiredasi penting bagi MNCs yang mentargetkan pasar global.

\section{Eksplanasi Investasi Asing Melimpah di Tengah Institusi Yang Buruk Di Tiongkok}

Dalam kajian bisnis investasi, ada beberapa pertimbangan investor (baik MNCs maupun perusahaan asing) 
dalam melabuhkan investasinya di negara berkembang diantaranya adalah pasar, sumber daya alam maupun sumber daya manusia, infrastruktur, stabilitas politik, stabilitas keuangan dan kualitas institusi di negara tersebut. Dari beberapa faktor di atas, berbagai studi klasik seperti yang dicetuskan oleh Hymer (1960), Kindleberger (1969), Dunning (1973) dan Buckley (1985) mengenai motif MNCs berinvestasi sepertinya masih revelan hingga saat ini. Hasil pemikiran mereka secara umum menunjukkan bahwa faktor utama MNCs berinvestasi adalah karena faktor ekonomi bisnis seperti pasar dan sumber daya yang dimiliki negara tujuan sebagai locational advantages. Faktor seperti stabilitas politik, kualitas institusi dan infrastruktur menjadi faktor tambahan (secondary factors) dalam masuknya investasi asing ke sebuah negara.

Dikaitkan dengan kasus Tiongkok, digaungkan sebagai negara yang menerima FDI kedua terbesar di dunia, pemberitaan media asing terhadap buruknya kualitas pemerintahan Tiongkok masih berlanjut. Meskipun demikian, pemberitaan tersebut tidak mempengaruhi minat investor untuk berbisnis di Tiongkok. Secara teoritis, Joseph P.H. Fan dkk menjelaskan bahwa korelasi FDI dengan institusi yang baik bisa diukur dari beberapa elemen dalam pemerintahan yaitu: (1)
Kualitas pemerintahan secara umum. Hal ini bisa dilihat dari bagaimana pemerintah tersebut melindungi hak milik swasta dan bebas atau minim dari tindakan korupsi; (2) Terbatasnya kekuasaan eksekutif. Aspek ini berkaitan dengan terbatasnya intervensi kepala pemerintah terhadap mekanisme bisnis yang berjalan. Dalam konteks lain, aspek ini mencegah kepala pemerintahan suatu negara dari tindakan atau keputusan sewenang-wenang yaitu membatalkan atau memodifikasi kontrak atau hak milik dan mengubah aturan permainan ekonomi dengan cara lain; (3) Track record pemerintah. Ini berhubungan dengan kinerja pemerintah untuk menjaga kestabilan pertumbuhan yang pesat di masa lalu sehingga menarik investor asing terlepas dari penilaian baik buruknya institusi-institusi yang dimiliki negara tersebut (Fan, Morck, Xu \& Yeung, 2009).

Kasus FDI melimpah dan institusi yang buruk di Tiongkok yang dianalisis dengan menggunakan 3 elemen di atas menunjukkan bahwa elemen ketiga yakni track record Tiongkok dalam menjaga pertumbuhan ekonomi menjadi faktor dominan yang mampu menjelaskan melimpahnya FDI yang masuk di negara tirai bambu tersebut terlepas dari elemen yang pertama yakni kualitas pemerintahan secara umum (Fan, Morck, Xu \& Yeung, 2007). Hal 
ini menegaskan bahwa institusi yang buruk dalam arti kualitas pemerintahan secara umum yang buruk di Tiongkok tertutupi dengan track record pemerintah Tiongkok yang mampu menjaga kestabilan pertumbuhan ekonomi yang pesat. Ini mengisyaratkan bahwa jika Tiongkok memiliki institusi yang baik dalam arti kualitas pemerintahan secara umum yang lebih baik, FDI yang masuk juga akan semakin besar. Ini juga bisa berarti bahwa elemen institusi yang baik dilihat dari kualitas pemerintahan secara umum berupa tingkat korupsi dan perlindungan hak milik swasta atas risiko pengambil alihan, repuditation (repuditasi) kontrak pemerintah, dan sebagainya kurang mendapatkan atensi yang besar.

Selain track record pemerintah Tiongkok, elemen kedua institusi yang baik dilihat dari terbatasnya kekuasaan eksekutif ternyata menjadi pertimbangan yang mendasar bagi investor di Tiongkok. Ini menegaskan secara implisit bahwa para investor asing menginginkan sebuah mekanisme pasar dimana pemerintah Tiongkok khususnya level eksekutif tidak melakukan intervensi yang sewenang-wenang di luar kontrak atau aturan pemerintahan dalam hal bisnis yang melibatkan perusahan domestik dan perusahaan atau invesot asing. Meskipun menjadi pertimbangan penting, para investor sepertinya cenderung mengabaikan elemen terbatasnya kekuasaan eksekutif (Fan, Morck, Xu \& Yeung, 2009). Hal ini dikarenakan kekuasaan eksekutif yang besar di Tiongkok justru dimanfaatkan oleh para investor asing untuk melakukan penyogokan agar pejabat di level eksekutif bisa mengeluarkan sebuah keputusan yang meyakinkan dan terlegitimasi untuk menguntungkan para investor asing atau bisa disebut "absolute power tends to be abused or bribed". Bahkan beberapa data menunjukkan bahwa bribery atau penyogokan kepada pejabat di Tiongkok dilakukan telah merajalela dan menjadi budaya yang umum dalam praktik bisnis yang melibatkan pemerintah dengan pebisnis maupun investor asing (Chow, 2018). Dalam kasus-kasus yang terjadi, praktik penyogokan oleh investor, atau pemerasan oleh pejabat pemerintah bahkan dilakukan secara terangterangan, tidak lagi sembunyisembunyi atau undertable.

Penjelasan di atas menunjukkan bahwa track record pemerintah Tiongkok yang mampu menjaga kestabilan pertumbuhan ekonomi yang pesat menjadi hal paling penting bagi para investor dalam konteks institusi yang baik. Elemen kualitas pemerintahan secara umum bukanlah pertimbangan penting. Sedangkan elemen terbatasnya kekuasaan eksekutif meskipun dianggap penting namun juga bukan masalah bagi para investor. Justru elemen ini menjadi katalisator 
bagi tindakan penyuapan dan penyogokan di Tiongkok oleh para investor asing.

Dalam kasus investasi asing dan institusi, penjelasan di atas juga membuktikan bahwa pentingnya institusi yang baik yang direkomendasikan sesuai standar IDPE sebagai konsiderasi penting dalam investasi tidak berefek signifikan. Apa yang diingikan investor berbeda dengan apa yang direkomendasikan sesuai standar IDPE mengenai institusi yang baik yakni apakah negara tersebut demokrasi atau non demokrasi dan apakah negara tersebut menjunjung penegakan hukum yang baik atau tidak, dsb. Investor yang membidik investasi khususnya di negara berkembang juga cenderung lebih mengutamakan faktor besarnya pasar dan kurang menganggap penting hal-hal yang berkaitan dengan institusional (Peres, Ameer \& Xu). Ini bisa menegaskan bahwa meskipun sebuah negara memiliki institusi yang baik, belum tentu banyak investor yang akan melabuhkan investasinya di negara tersebut, jika negara tersebut tidak memiliki keunggulan locational advantages.

Dalam penjelasan lain, kesuksesan Tiongkok dalam menarik FDI yang berdampak pada tingkat pertumbuhan ekonomi yang tinggi di tengah institusi yang buruk dapat ditinjau dari konteks model birokrasi. Meskipun Tiongkok bukan negara demokratis dan memiliki indeks korupsi yang tinggi serta kualitas pemerintahan yang buruk namun fakta menunjukkan bahwa model birokrasi di Tiongkok mampu menciptakan iklim yang bagus untuk FDI dan mampu memberikan dampak pada pembangunan ekonomi yang pesat. Tiongkok menerapkan model birokrasi organisasi kader. Model organisasi ini berbeda dengan model weberian yang pada umumnya diterapkan di negara-negara demokrasi dunia saat ini khususnya negara-negara Barat. Dengan kata lain, Tiongkok menerapkan model birokrasi sesuai kultur negaranya yang berbeda dengan kultur negara-negara Barat.

Model organisasi kader menekankan pada pentingnya komitmen ideologi terhadap doktrin kebijakan tertentu. Para personelnya biasanya dilatih untuk cekatan dalam mengikuti perubahan ideologi operatif yang datang dari atasan (Rothstein, 2015). Para bawahan memposisikan sebagai anggota yang memiliki kepatuhan yang tinggi terhadap perintah atasan atas dasar komitmen ideologi. Meskipun jelas bertentangan dengan nilai-nilai demokrasi universal dan model weberian namun model birokrasi seperti ini ternyata sangat cocok (bagi Tiongkok) untuk mengimplementasikan kebijakan ekonomi dan sosial pembangunan 
secara efektif yang mengutamakan efisiensi untuk menghasilkan nilai outcome yang tinggi. Selain itu, model ini juga mampu meningkatkan legitimasi politik dari pengambil kebijakan (Rothstein, 2015) yang diyakini sebagai kelompok yang sangat mengutamakan dan menjunjung tinggi kepentingan nasional.

\section{KESIMPULAN}

Tiongkok adalah contoh negara destinasi FDI dalam jumlah yang melimpah tengah institusinya yang buruk. Kondisi ini meruntuhkan berbagai paradigma teoritis yang ada bahwa negara yang memiliki institusi yang buruk juga dapat menarik MNCs atau investor asing untuk melabuhkan investasinya di negaranya. Locational advantages yang dimiliki Tiongkok yakni jumlah konsumen domestik yang sangat besar, upah buruh yang relatif rendah dan akses pasar global yang luas sebagai akibat dari favorable policies menjadi pertimbangan paling fundamental bagi MNCs untuk berivestasi di Tiongkok.

Dalam konteks institusi, korelasi FDI dengan institusi dapat diukur dari elemen; kualitas pemerintahan secara umum, terbatasnya kekuasaan eksekutif dan track record pemerintah. Elemen track record pemerintah Tiongkok yang mampu menjaga pertumbuhan ekonomi yang pesat menjadi faktor penarik MNCs atau investor asing dan seakan menutupi dua elemen lainnya. Elemen kualitas pemerintahan secara umum berupa tingkat korupsi dan perlindungan hak milik swasta atas risiko pengambil alihan, dan sebagainya kurang mendapatkan atensi yang besar. Elemen terbatasnya kekuasaan eksekutif memang menjadi pertimbangan penting investor asing di Tiongkok, namun elemen ini justru diabaikan atau malah dimanfaatkan para investor asing untuk penyuapan dan penyogokan. Ditinjau dari model birokrasi, kesuksesan Tiongkok dalam menarik FDI yang berdampak pada tingkat pertumbuhan ekonomi yang tinggi di tengah institusi yang buruk tidak lepas dari model birokrasi organisasi kader yang menekankan pentingnya komitmen ideologi terhadap doktrin dalam mengimplementasikan kebijakan ekonomi dan sosial pembangunan secara efektif.

\section{REFERENSI}

Boittin, M., Distelhorst, G., \& Fukuyama, F. (2016) "Reassessing the Quality of Government in China", Osgoode Legal Studies Research Paper Series, No.197, p. 4.

Bose, T.K.. (2012) “Advantages and Disadvantages of FDI in China and India", International Business Research, Vol.5, No. 5, p. 167.

Buckley, P.J.,\& Casson, M. (1985) The Economic Theory of the Multinational Enterprise. London: Macmillan Press. 
Ceglowski, J., \& Gollub, S. (2018) "Just How Long are China's Labour Costs?", The World Economy, Vol. 30, No. 4, p. 611.

Chang, H.J. (2002) Kicking Away the Ladder: Development Strategy in Historical Perspective, London: Anthem Press.

China Labour Bulletin. (2019) Employment and Wages (Online). Available at: https://clb.org.hk/content/employment -and-wages Diakses: 23 Mei 2019).

Chow, D.C.K. (2018) “How China's Crackdown on Corruption Has Led to Less Transparency in the Enforcement of China's Anti-Bribery Laws", Texas A\&M Law Review, Vol. 5(2), pp.691692.

Dunning, J.H. (1973) "The Determinants of International Production", Oxford Economic Paper, Vol. 25(3), pp. 289-300.

Fan, J.P.H., Morck, R., Xu, L.C., \& Yeung, B. (2007) 'Does 'Good Government' Draw Foreign Capital? Explaining China's Exceptional Foreign Direct Investment Inflow", World Bank Policy Research Working Paper, No. 4206, April, p. 4.

Fan, J.P.H., Morck, R., Xu, L.C., \& Yeung, B. (2009) "Institutions and Foreign Direct Investment: China, versus the Rest of the World", World Development, Vol.37(4), pp. 852-853.

Fruman, C. (2016) What does efficiency-seeking FDI matter? (Online). Available at: https://blogs.worldbank. org/psd/whydoes-efficiency-seeking-fdi-matter (Diakses: 21 Januari 2019).

Graham A. (2018) Is War Between China and the U.S Inevitable? [Video] Directed by: TED (Online). Available at: https://www.ted.com/talks/graham_alli son_is_war_between_china_and_the_us _inevitable/transcript\#t-71389 (Diakses: 8 Juni 2019).

Hayat, A. (2019) "Foreign Direct Investments, Institutional Quality and
Economic Growth", The Journal of

International Trade \& Economic

Development, Vol. 28(5), p. 15.

Hymer, S.H. (1960) The International Operations of National Firms: A Study of Foreign Direct Investment, MIT Press.

Jiefei, L. (2019) China's Services Sector Expands at Fastest Pace in 15 Months: Caixin Survey (Online). Available at:

https://www.caixinglobal.com/201905-06/chinas-services-sector-expandsat-fastest-pace-in-15-months-caixinsurvey-101410645.html Diakses pada 9 Mei 2019).

Kindleberger, C. P. (2002) American Business Abroad: Six Lectures on Direct Investment Yale University Press. New Haven, 1969 dalam Rugman, Alan. M., International Business: Theory of the Multinational enterprise (Vol.1), Rouledge, London \& New York. pp. 134-151.

Oatley, T. (2012) International Political Economy (5th Edition), Pearson Longman.

Peres. M., Ameer.W., \& Xu.H. (2018) “The Impact of Institutional Quality on Foreign Direct Investment Inflows: Evidence for Developed and Developing Countries", Economic Research-Ekonomska Istraživanja, Vol. 31(1), pp. 626-644.

Plekhanov, D. (2017) Is China's Era of Cheap Labor Really Over? (Online). Available at: https://thediplomat.com/2017/12/ischinas-era-of-cheap-labor-really-over/ (Diakses: 23 Juni 2019).

Rothstein, B. (2015) “The Chinese Paradox of High Growth and Low Quality of Government: The Cadre Organization Meets Max Weber", Governance, Vol. 28(4), pp.533-548.

Santandertrade. (2019) China: Foreign Investment (Online). Available at: https://en.portal.santandertrade.com/e stablish-overseas/china/foreigninvestment (Diakses: 2 Juli 2019). 
Shah, M.H. \& Afridi, A.G. (2015)

"Significance of good governance for FDI inflows in SAARC Countries", Business \& Economic Review, Vol. 7(2), p. 32.

Taube, M. (2002) "Main Issues on Foreign Investment in China's Regional Development: Prospects and Policy Challenges", Organisation for Economic Cooperation and Development (Online). Available at:

https://www.oecd.org/investment/inv estmentfordevelopment/1939560.pdf

(Diakses : 1 Januari 2019).

Transparency. (t.t) China (Online). Available at:

https://www.transparency.org/country /CHN (Diakses: 3 Juli 2019).

Tripathi, R. (2017) "Good Governance: Origin, Importance and Development in India", International Journal of Development Research, Vol. 07(11), pp. 16968-16970.
World Bank. (2018) Doing Business Report: China Carries Out Record Business Reforms, Edges into Top 50 Economies (Online). Available at: https://www.worldbank.org/en/news/ press-release/2018/10/31/doingbusiness-report-china-carries-outrecord-business-reforms-edges-intotop-50-economies (Diakses: 29 Juni 2020).

Yang, D.T., Chen, V.W., \& Monarch, R., 'Rising Wages: Has China Lost its Global Labor advantage?', Pacific Economic Review, vol. 15, no/issue. 4, 2010, p. 482. 